\title{
Fotografia e pintura: relação mútua no distanciamento da mimese
}

\section{Photography and painting: mutual relation in the distancing from mimesis}

Ana Karina Tamoto do Prado ${ }^{1}$ 


\section{Resumo}

Por meio de um breve levantamento histórico crítico, este artigo tem por objetivo mostrar a transformação do pensamento ocidental acerca do caráter mimético da representação na pintura e como a fotografia desempenhou papel importante nessa mudança, em que se deslocou para ela o compromisso com a cópia da realidade. A investigação considera o conceito de mimese ponderado por Platão e Aristóteles acerca da arte, que teve como uma de suas consequências a valorização da semelhança com a realidade numa obra artística, reflexão que permeou a estética ocidental durante muito tempo. Ao evidenciar as tentativas iniciais de desvincular a produção pictórica e fotográfica da imposição de buscar a verossimilhança, os movimentos modernistas explicitam tendências e tentativas de recolocar o problema da representação.

Palavras-chave: Mimese. Fotografia. Pintura. Representação.

\section{Abstract}

Through a brief critical historical study, this article aims to show the transformation of occidental thought about the mimetic character of representation in painting and how photography performed an important role in this change, when it transferred for her the compromise with the copy of reality. The investigation considers the concept of mimesis pondered by Plato and Aristotle about the art, which had as one of its consequences the appreciation for similarity to reality in an artistic work, reflection which permeated the occidental esthetics for a long time. By showing initial attempts to unlink pictorial and photographic production from the imposition of seeking the verisimilitude, modernist movements reveal trends and attempts to replace the problem of representation.

Keywords: Mimesis. Photography. Painting. Representation.

${ }^{1}$ Formanda do Curso Superior de Tecnologia em Fotografia da Universidade Tuiuti do Paraná, realizando trabalhos na área. Brasil. 


\section{INTRODUÇÃO}

Desde que passou a viver em sociedade, o ser humano buscou se comunicar e eternizar a sua existência por meio de figuras. Mesmo com o advento da escrita, 0 fascínio pelas imagens permaneceu. A possibilidade de se obter um espelho do mundo fez com que em muitos períodos da história a representação do real se desse por meio delas. Hoje, grande parte das sociedades contemporâneas valoriza o caráter audiovisual das comunicações.

Esse fenômeno foi estudado na Grécia antiga, onde a tentativa de representar a realidade era atividade ligada às artes e estava vinculada ao conceito de mimese, que, no grego, significa imitação. As reflexões advindas dos grandes pensadores atenienses, da arte como mimese, forneceram as bases da estética ocidental durante muito tempo, acorrentando artistas a padrões formais estabelecidos.

Entretanto, essas amarras foram desfeitas e surge uma nova forma de se pensar a arte. Este artigo traça um breve panorama do processo do distanciamento da mimese na história da arte, em que se percebe a relação entre pintura e fotografia justamente na questão da representação da realidade.

A arte fotográfica desempenhou um papel importante no rompimento da pintura com a mimese e acabou transferindo para si a função da cópia da realidade. Por outro lado, as conquistas obtidas na arte pictórica levaram a uma nova forma de se pensar a fotografia.

\section{A REPRESENTAÇÃO DA REALIDADE EM PLATÃO E ARISTÓTELES}

Para entender a mimese buscamos a fonte dos seus estudos, os filósofos gregos Platão e Aristóteles, uma vez que as reflexões que a eles se sucederam foram, de um modo geral, reformulações de seus conceitos (RAFFAELLI e MAKOWIECKY, 2000). Este artigo se concentra na relação da arte mimética com a imagem pictórica e fotográfica ${ }^{1}$, embora o sentido da mimese tenha sido trabalhado de formas diversas por diferentes áreas.

Platão (circa 427-347 a.C.) estabelece a existência de dois mundos, o mundo das ideias, onde tudo existe em sua essência², e o mundo sensível (aquele em que vivemos), o qual foi criado como cópia imperfeita daquele. Para o filósofo, a arte está ligada ao mundo das ideias, devendo basear-se na essência das coisas, o que, segundo ele, não acontece. O artista acaba apenas realizando uma cópia do que existe no mundo sensível e nada apreende da essência das coisas, constituindo-se mero imitador.

Se para Platão a nossa realidade já é uma cópia imperfeita da essencial, então

\footnotetext{
1 Tanto em A República, de Platão, quanto em Poética, de Aristóteles, o conceito de mimese foi trabalhado com a poesia e a dança, no entanto, sua aplicação não se restringia a esse contexto, aplicava-se também às manifestações visuais e plásticas.

2 Essência, em Platão, é o que verdadeiramente existe daquilo que se tem no mundo concreto; é a verdade das coisas; é aquilo que delas permanece no mundo das idéias.
} 
a obra de arte é a cópia da cópia e o pintor está 3 vezes distante da verdade ${ }^{3}$. Isso posto, o ateniense ainda afirma ser impossível uma pessoa ser conhecedora de todas as coisas e de todos os ofícios, a ponto de realizar uma cópia perfeita. Logo, a pintura resultaria apenas em uma parte da coisa retratada, a parte do objeto aparente ao artista. "O imitador nada entende da realidade, apenas da aparência". A obra é um fantasma e não coisa real" (PLATÃO, 2000, p. 300). Portanto, para realizar a cópia perfeita do objeto, o artista deve conhecê-lo em todos os seus aspectos, o que é impossível, segundo o filósofo.

Dessa forma, Platão repudia a arte mimética, que destrói a inteligência do espectador, visto que este não conhece o objeto em sua verdadeira natureza. Frente à obra mimética, as pessoas estão muito longe da verdade e, não sabendo diferenciar a ciência da imitação, correm o risco de serem enganadas.

Sendo assim, para tornar a tarefa da imitação menos prejudicial, menos submetida ao que os objetos aparentam ser ao artista, Platão confia nas ferramentas que estabelecem os padrões métricos das coisas:

\footnotetext{
- E os mesmos objetos parecem tortos ou direitos, para quem os observa na água ou fora dela, côncavos ou convexos, devido a uma ilusão de óptica proveniente das cores, e é evidente que aqui há toda a espécie de confusão na nossa alma. Aplicando-se a esta enfermidade da nossa natureza é que a pintura com sombreados não deixa por tentar espécie alguma de magia, e bem assim o teatro de marionetes e todas as outras habilidades do gênero.

- É verdade.

- Mas não inventaram a medição, o cálculo, a pesagem, como auxiliares preciosos contra esses inconvenientes, de tal modo que não prevalece em nós a aparência de maior ou menor, mais numeroso ou mais pesado, mas o que se calculou, mediu ou pesou?

- Sim!

- Ora, realmente, essas operações podem ser o trabalho da razão que está na nossa alma.

(PLATÃO, 2000, p. 301)
}

Para o filósofo, a parte da alma que julga as coisas sob as medidas estabelecidas é a melhor parte e, o contrário, a que julga de acordo com a aparência que se tem das coisas, a pior.

Seguindo-se a Platão, seu discípulo, Aristóteles (384-322 a.C.), também estuda as questões artísticas. Assim como seu mestre, acredita que o cerne da arte é a imitação da realidade, pois a mimese é algo intrínseco ao ser humano, desde a infância, por meio da qual se adquire conhecimentos e se experimenta o prazer. Entretanto, seu estudo neste campo não é uma crítica à imitação da realidade, nem abarca as questões existenciais da arte ou suas implicações, como em Platão. Aristóteles afasta a arte mimética das questões ontológicas e a aproxima da estética (COSTA, 1992).

Embora para este filósofo a arte continue a ser definida como imitação da realidade, o que se produz não é uma simples cópia do real e aquilo que o objeto aparenta ser ao artista. A obra é o resultado da junção do objeto real com o artista, constituindo uma terceira coisa. Se o pintor realiza o quadro de uma cama, o que se produz é

\footnotetext{
3 Para Platão, a verdade é aquilo que existe no mundo das ideias.

4 Aparência é a parte do objeto percebida/entendida pelo artista.
} 
a pintura de uma cama, e não a aparência de uma cama, destituída de sua essência.

Acerca dessa relação do artista com o objeto a ser imitado, Aristóteles afirma que o imitador, perante os objetos, será induzido a imitá-los por meio de uma das três maneiras de imitação: como as coisas eram ou são, como os outros dizem que são ou como parecem ser, ou como deveriam ser. (ARISTÓTELES, 2003). Assim, a mimese não se restringe a uma única visão do objeto, ela é pautada num possível dimensionado por essas três formas (COSTA, 1992), ou seja, Aristóteles assume que a obra de arte pode ser semelhante à realidade e não cópia fiel, adentrando o campo do "pode ser" e se distanciando do campo da essência.

Afastando-se das questões existenciais da arte mimética, o filósofo se interessa pelo processo de imitação em si. A mimese passa a ser um processo construído segundo critérios. Em Poética, Aristóteles dedica-se a analisar a estrutura da representação e a descrever os seus elementos, como se deve constituí-la a fim de atingir o belo poético:

\begin{abstract}
Além disso, o belo, em um ser vivente ou num objeto composto de partes, deve não só apresentar ordem em suas partes como também comportar certas dimensões. Com efeito, o belo tem por condições uma certa grandeza e a ordem. Por este motivo, um ser vivente não pode ser belo, se for excessivamente pequeno (pois a visão é confusa, quando dura apenas um momento quase imperceptível), nem se for desmedidamente grande (neste caso o olhar não abrange a totalidade, a unidade e o conjunto escapam à vista do espectador, como seria o caso de um animal que tivesse de comprimento dez mil estádios). Daí se infere que o corpo humano, como o dos animais, para ser julgado belo, deve apresentar certa grandeza que torne possível abarcá-lo com o olhar; do mesmo modo as fábulas devem apresentar uma extensão tal que a memória possa também facilmente retê-las. (ARISTÓTELES, 2003, pp. 39-40)
\end{abstract}

Ao delimitar a extensão das fábulas, Aristóteles demonstra que, apesar da arte mimética não produzir apenas uma simples cópia da realidade e sim uma possível interpretação do real por meio de algo que poderia ser, esse "possível" acaba sendo restringido à sua concepção de belo, que remete a algo que pode ser medido, cujas dimensões ele mesmo comenta. Ademais, embora afirme que compete ao poeta representar algo que poderia ter acontecido (o possível), ele o deve fazer segundo a verossimilhança (provável) ou a necessidade (lógico) (COSTA, 1992). Projetando tal idéia às artes plásticas, entende-se que a representação deve ser visualmente semelhante à realidade.

O elemento básico da tragédia é sua própria alma: a fábula; e só depois vem a pintura dos caracteres. Algo de semelhante se verifica na pintura: se o artista espalha as cores ao acaso, por mais sedutoras que sejam, elas não provocam prazer igual àquele que advém de uma imagem com os contornos bem definidos. (ARISTÓTELES, 2003, p. 37)

Apesar de existir uma diferença de visões acerca da arte mimética entre os dois filósofos, é importante perceber que ambos definem padrões a serem seguidos no que tange à forma de representar o real, a fim de que a representação seja convincente, com proporções ideais e harmonia das formas, assemelhando-se, assim, à realidade concreta.

Essa concepção de arte como imitação e os padrões estéticos advindos desse 
entendimento, os quais determinaram a semelhança com a realidade ser o principal critério a se admirar numa obra de arte, prevalecem no pensamento ocidental até o final do século XIX $X^{5}$, quando surge a fotografia, que já nasce caracterizada pela mimese.

\section{DISTANCIAMENTO DA MIMESE NA PINTURA}

Para demonstrar o papel da fotografia no distanciamento da mimese na pintura e a relação de representação da realidade entre as duas artes, é importante retratar brevemente como determinadas mudanças de visões se deram, uma vez que o efetivo afastamento se trata da quebra de padrões estabelecidos.

Os primeiros passos em direção ao distanciamento do caráter mimético da pintura foram dados por movimentos que ainda evidenciavam a semelhança com o real, mas que de alguma forma indicavam uma mudança de padrões.

O Romantismo (1850-1870), valorizando a imaginação, a criatividade e os sentimentos, desloca o objeto de uma representação do mundo exterior para a representação de um mundo interior, ainda que de forma mimética. Na obra A Liberdade Guiando o Povo (FIGURA 1), de Eugène Delacroix (1798-1863), o pintor materializa o sentimento "liberdade" no corpo de uma mulher, a fim de fornecer o aspecto de real àquilo que vem da imaginação.

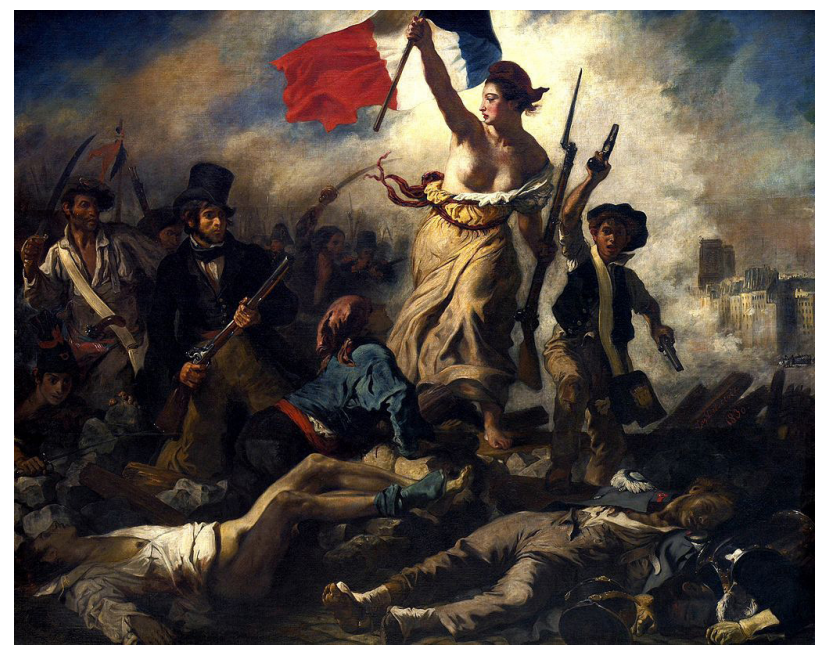

FIGURA 1 - A Liberdade Guiando o Povo, EugèneDelacroix, 1830 Fonte: http://www.sociologia.seed.pr.gov.br

Já o Realismo (1850-1870), movimento que, apesar da mimese ser visível e necessária, inicia uma mudança na forma de se fazer arte, uma vez que reage ao academicismo e aos padrões reafirmados pelo Renascimento e pelo Neoclassicismo ${ }^{6}$. Prezavam pelo retrato da realidade tal como ela é, registrando objetivamente a na-

5 Com exceção da Idade Média, em que a arte estava aos préstimos da religião, e de alguns movimentos artísticos de pouca duração, como o maneirismo.

6 Trata-se de dois movimentos que retomaram os ideais da arte greco-romana, valorizando a busca pela representação perfeita da natureza, o que era obtido por meio de estudos e racionalização do processo artístico, estando relacionados ao academicismo. 
tureza e retratando o cotidiano das classes médias e baixas, como crítica ao tradicionalismo e clichês burgueses. Gustave Courbet (1819-1877), representante dessa mudança de pensamento, tinha seus quadros como forma de protesto, não trabalhando para agradar alguém ou para vender melhor, mas de acordo com a sua consciência, pintando o mundo tal como o via. Em sua obra Bonjour Monsieur Coubert (FIGURA 2), ele simplesmente pinta uma cena do cotidiano, sem tradições formais e tema eloquente.

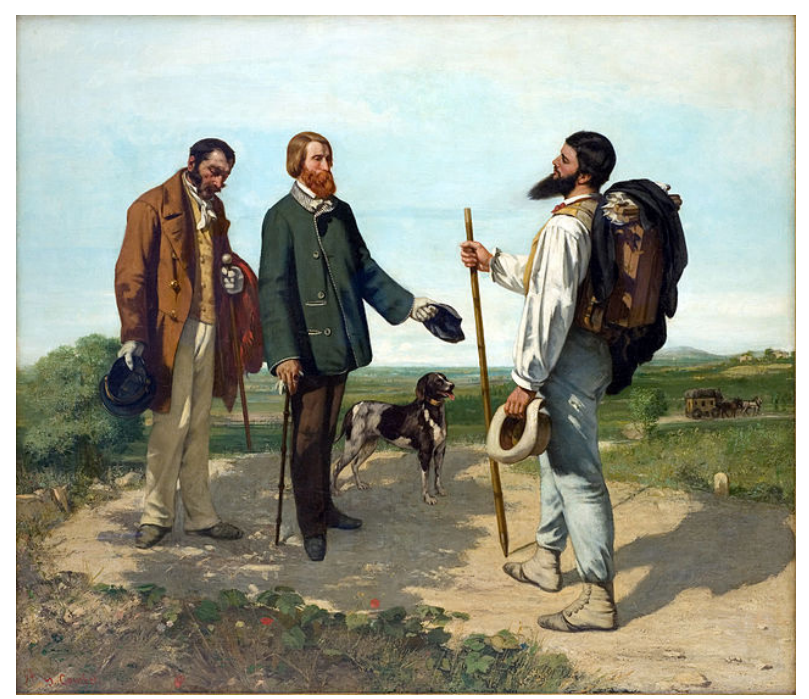

FIGURA 2 - Bonjour Monsieur Coubert, Gustave Courbet, 1854 Fonte: GOMBRICH, 2008

Os adeptos do movimento que sucedeu o Realismo levaram além a ideia de representar o mundo conforme eles o viam e marcaram o início da maior revolução na forma de representar na história da arte.

Para os artistas pertencentes ao Impressionismo, a maneira tradicional de se pintar em ateliês fechados era condição muito artificial, preferindo trabalhar em áreas externas. Descobriram que os objetos observados ao ar livre não estão sujeitos às cores e formas determinadas por convenções. Uma vez dispostos sob a luz natural, os motivos se apresentam de acordo com o momento e variam com o tempo e a alteração da luminosidade, do mesmo modo que pertencem a um todo, cujos matizes se combinam em nossas mentes. (GOMBRICH, 2008)

Para esses artistas, a impressão que temos do mundo é efêmera. As coisas, assim como as vemos, não são estáticas, estando sempre em movimento; tampouco são completamente nítidas, pois nossa visão é seletiva e não tem todos os objetos em foco; portanto, não seguem determinados padrões formais.

A obra Baile no Moulin de La Galette (FIGURA 3), de Pierre-Auguste Renoir (18411919), demonstra como os impressionistas trabalham essa efemeridade, utilizando pinceladas visíveis e contornos não nítidos, dando a impressão de movimento, bem como o estudo da luz no ambiente, com os feixes que projetam as sombras das folhagens nos personagens e as diferentes nuances de cores do motivo. 


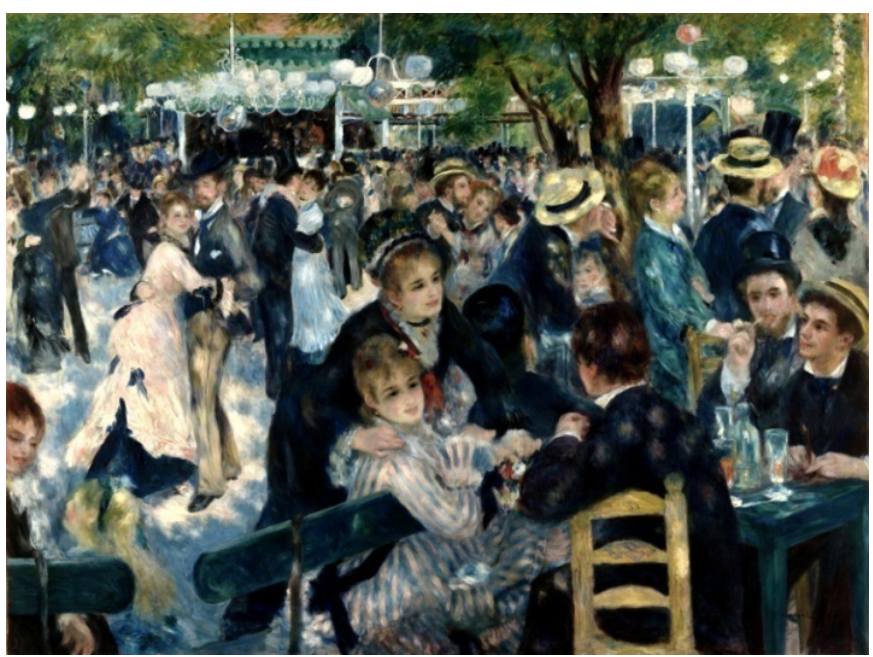

FIGURA 3 - Baile no Moulin de La Galette, Pierre-Auguste Renoir, 1876 Fonte: GOMBRICH, 2008

Esses artistas não se desprenderam completamente da mimese, já que seu desejo ainda era representar a realidade visual, mesmo que ela se apresentasse de forma efêmera e sem nitidez. Por outro lado, a mudança se deu ao considerarem a subjetividade com que o artista percebe o mundo. Afastaram-se da mimese no momento em que não possuíam mais a rigidez formal anterior, suas pinturas eram compostas por desenhos que não obedeciam às perspectivas euclidianas ${ }^{7}$ e as pinceladas eram visíveis, formando manchas coloridas e cheias de luz

Os velhos chavões do "tema digno", da "composição equilibrada", do "desenho correto" foram sepultados. O artista só era responsável pelo que pintava e como pintava ante a sua própria sensibilidade. (GOMBRICH, 2008,p. 522)

Esses artistas foram ridicularizados no início do movimento, por apresentarem trabalhos fora dos padrões miméticos e formais até então estabelecidos. Excluídos de exposições oficiais (os Salões), encontravam meios de se inserir na vida social. Em 1874, o fotógrafo Gaspard-Félix Tournachon (1820-1910), conhecido como Nadar, envolvido com a causa dos impressionistas, abriu seu estúdio para a realização da primeira exposição impressionista, ajudando a despontar esses artistas, os quais eram, em sua maioria, seus amigos.

Não se passaram muitos anos para que os impressionistas alcançassem o reconhecimento social. A sua luta acabou sendo recompensada e suas concepções aceitas. Esses pintores trouxeram ao mundo das artes plásticas não apenas uma mudança formal, mas despertaram a crítica para um novo olhar, em que reconhecer e aceitar novos métodos era o novo caminho.

Para Gombrich, toda essa transformação de pensamento se deu com grande auxílio de um novo invento, a fotografia ${ }^{8}$.

7 Perspectivas ligas à geometria euclidiana, que trabalha em duas e três dimensões, baseada nos postulados de Euclides de Alexandria.

8 Além da Fotografia, Gombrich cita também as gravuras japonesas do século XVIII, que chegaram à Europa devido à relação comercial entre este continente e 0 Japão. $O$ que chamou a atenção dos artistas impressionistas nessas estampas, além dos temas despretensiosos (em sua maioria cenas do dia a dia de pessoas humildes), era o fato 
A invenção da máquina fotográfica portátil e instantânea aconteceu ao mesmo tempo em que o impressionismo se desenvolvia. A tarefa de obter uma cópia da realidade passou a ser do fotógrafo e não mais do pintor, o que propiciou aos artistas liberdade para refletirem sobre sua arte e buscarem a experimentação. $O$ teórico francês Philippe Dubois cita Picasso, ilustrando essa mudança:

Por que o artista continuaria a tratar de sujeitos que podem ser obtidos com tanta precisão pela objetiva de um aparelho de fotografia? Seria absurdo, não é? A fotografia chegou no momento certo para libertar a pintura de qualquer anedota, e qualquer literatura e até do sujeito. Em todo caso, certo aspecto do sujeito hoje depende do campo da fotografia." (PICASSO, 1939, apud DUBOIS, 1998, p.31)

Ademais, o contato visual das pessoas com fotografias de cenas ocasionais e de ângulos inusitados ajudou o senso comum a se acostumar com uma forma diferente de ver o mundo.

O Impressionismo deu início à desmaterialização do objeto pintado e se desobrigou dos padrões formais, abrindo portas para artistas buscarem o novo. Foi assim que alguns, embora compartilhassem de certas idéias impressionistas, não se conformaram em apenas estudar a realidade sob um aspecto visual e, percebendo que thes faltava algo, buscaram seus próprios meios e ideais artísticos.

O grupo dos pós-impressionistas não era coeso, assim como seus artistas. Tal denominação se deu àqueles que, ao final do movimento impressionista, exploraram as possibilidades abertas por ele. Já não havia espaço para preceitos determinados de arte, não sendo possível elencar características próprias do movimento. Assim, para entendê-lo melhor, analisemos rapidamente os seus principais representantes: Paul Cézanne (1839-1906), Vincent van Gogh (1853-1890) e Paul Gauguin (1848-1903).

Cézanne empenhou-se em estudar a estrutura pictórica e não se importava em alterar as formas e perspectivas da cena em benefício da composição. Utilizava as cores para ressaltar o volume e peso dos objetos e procurava reduzir a natureza a suas formas fundamentais: esfera, cilindro e cone. Conforme se pode observar em uma de suas naturezas-mortas (FIGURA 4), a fruteira não possui simetria e as frutas de forma arredondada resumem-se a esferas. Já Van Gogh buscou a liberdade de expressar suas emoções, as quais são fortemente demonstradas em suas obras, tanto por suas intensas e definidas pinceladas, quanto pelo movimento de suas imagens e cores vibrantes, como em $A$ noite estrelada (FIGURA 5), encontrando na pintura um refúgio emocional para a sua personalidade oscilante. Por fim, Paul Gauguin, também ligado às emoções, desenvolveu um estilo de representação simbólica da natureza, com formas simplificadas e grandes campos de cores vivas chapadas. Tal simplificação pode ser examinada na obra Te Rerioa (Divagação) (FIGURA 6), na qual o artista deixa de se ater às formas e proporções reais do corpo humano, não evidenciando músculos ou detalhes demasiados. Diferentemente de Cézzane, não reduzia as imagens a formas geométricas, mas as sintetizava de maneira subjetiva.

delas não seguirem os padrões formais aos quais a arte ocidental estava condicionada. Eram desenhos que nem sempre retratavam uma cena completa, com toda a paisagem de fundo, às vezes apenas uma árvore ou um arbusto se sobressaía, outras cenas possuíam cortes inesperados, aos quais os olhos ocidentais não estavam acostumados. 


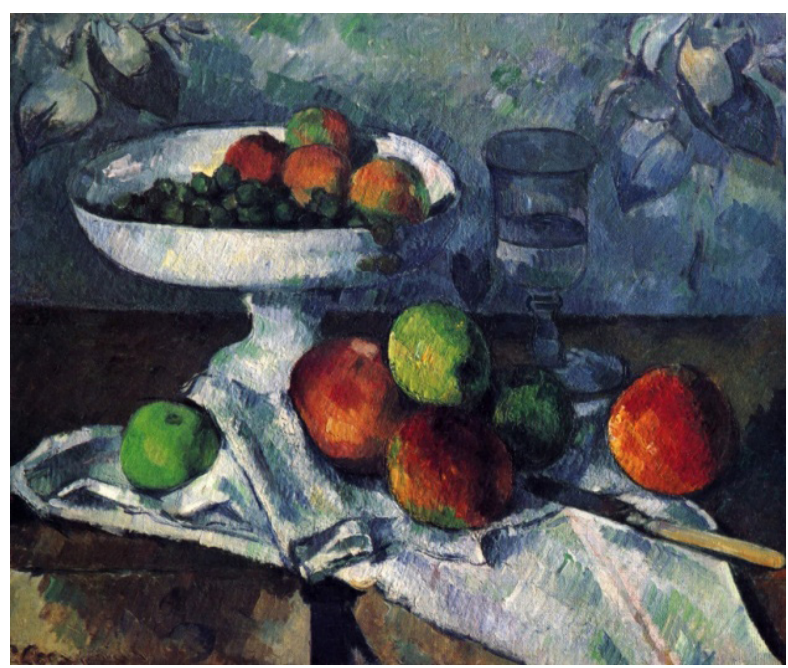

FIGURA 4 - Natureza-morta, Paul Cézanne, 1879-82 Fonte: GOMBRICH, 2008

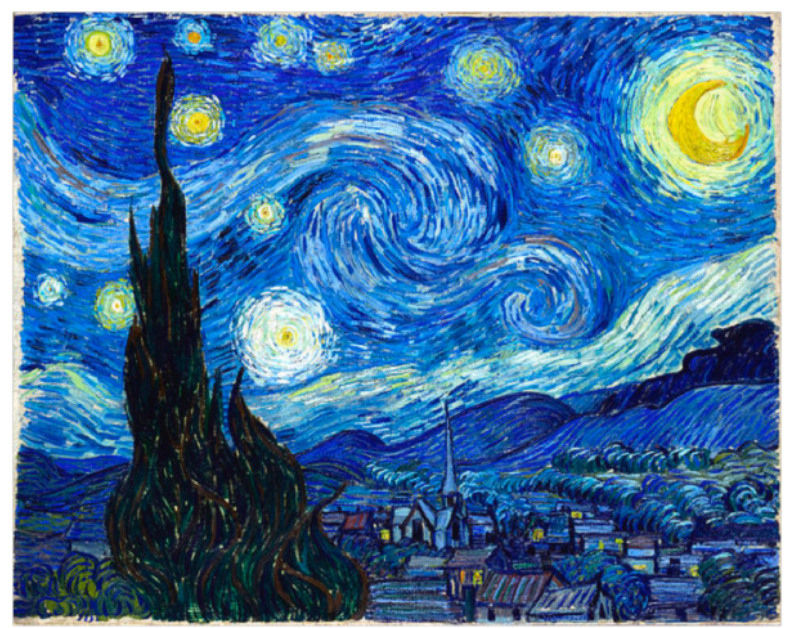

FIGURA 5 - A noite estrelada, Vincent van Gogh, 1889 Fonte: http://www.infoescola.com

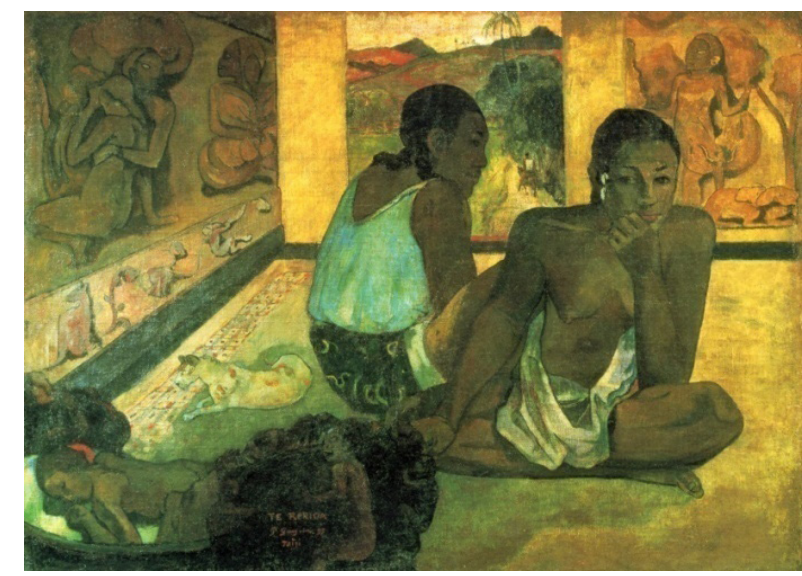

FIGURA 6 - Te Rerioa (Divagação), Paul Gauguin, 1897 Fonte: GOMBRICH, 2008

Embora tenham percorrido caminhos diferentes, esses três pintores tinham em comum a busca de maior subjetividade em suas artes e não se importaram em modificar o aspecto real das coisas a fim de adequar a obra ao seu propósito. Assim, "deram o passo importante de abandonar deliberadamente a finalidade da pintura como 
imitação da natureza" (GOMBRICH, 2008, pg. 548).

Esses três grandes artistas foram a base para os movimentos de vanguarda da Arte Moderna. Cézanne, com sua objetividade, está na raiz do cubismo. Gauguin e sua obra simplificada e simbólica influenciam o movimento simbolista. Por sua vez, Van Gogh delimita as orientações expressionistas futuras.

E é aqui que se consolida a ruptura definitiva com os padrões antes estabelecidos na arte e, especialmente, o rompimento da pintura com a mimese. Esses movimentos e o que se seguiu na Arte Moderna são caracterizados pela subjetividade, pela transmutação do meio e do objeto pelo artista, conforme sua vontade, pela expressão e a liberdade do sujeito.

\section{MIMESE E FOTOGRAFIA}

Embora o pensamento acerca da representação da realidade tenha chegado ao distanciamento da mimese com o pós-impressionismo, quando a fotografia surgiu, a reaproximação foi inevitável.

O fato de a fotografia fornecer um resultado muito semelhante ao do objeto retratado deu a ela um caráter estritamente mimético. Existia uma credibilidade em relação à documentação do real a ponto de tê-la como cópia fiel da realidade e assim cria-se que com ela se conseguisse provar a existência daquilo que era retratado. Tudo, é claro, reforçado pelo fato de ser produzida por uma máquina, dando-lhe o caráter objetivo.

Sucederam-se muitas discussões sobre a situação da pintura em relação à fotografia, em sua maioria com a finalidade de descobrir se esta viria a substituir aquela. No entanto, quando surgiu, atribuíram-se à fotografia somente os ofícios dos pintores relacionados ao registro da realidade, como retratos, paisagens, reportagens, ilustrações, documentação científica. Isso apenas mudou os rumos na pintura, influenciando o desenvolvimento de uma nova forma de se pensar arte e de novos movimentos artísticos, uma não substituiu a outra.

Foi um período em que se destacaram aqueles que cumpriam essa tarefa de registro, como Nadar e seus retratos (FIGURA 7) e William Henry Fox Talbot (1800-1877) e suas fotografias de plantas para os botânicos. Desenvolveu-se também a fotografia de caráter documental, com os registros de fatos históricos (FIGURA 8), as explorações de lugares longínquos (FIGURA 9), bem como os registros microscópicos e telescópicos ${ }^{9}$.

9 Imagem do sol, em 1845, por Fizeau, e da Lua, em 1851, por John Adams Whipple. 


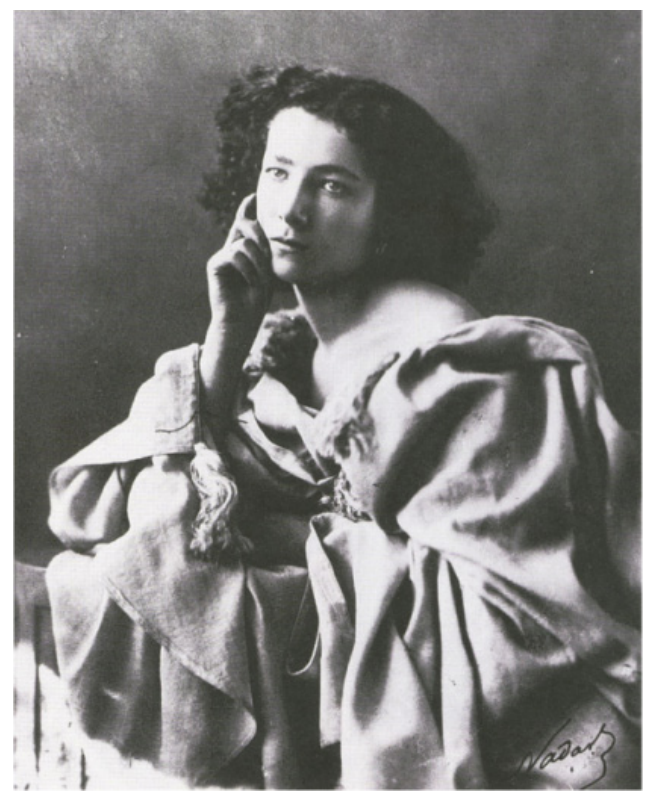

FIGURA 7 - Sarah Bernhardt, Nadar, 1864 Fonte: Tudo sobre Fotografia, 2012

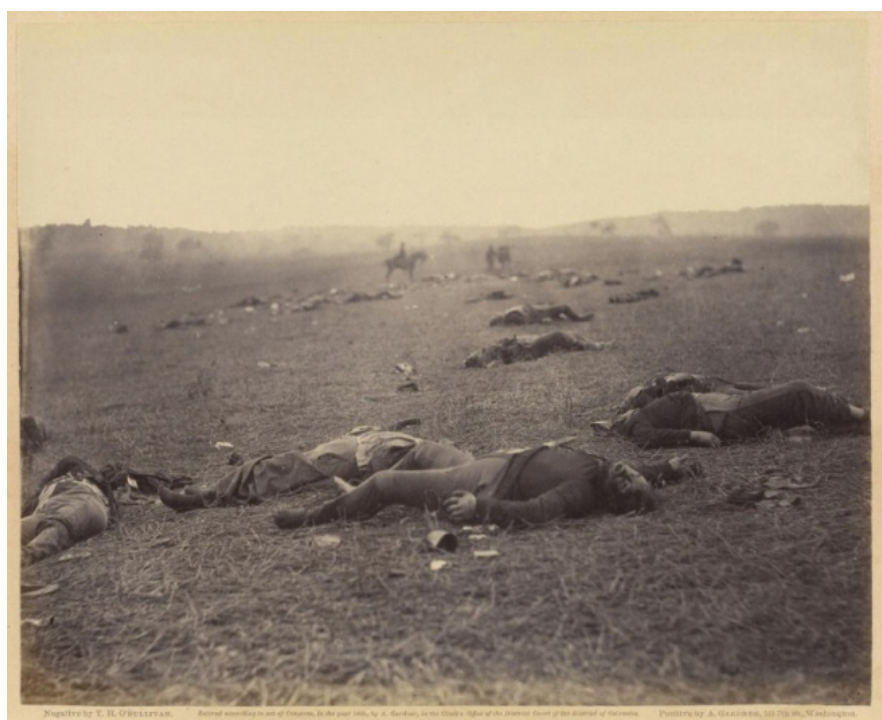

FIGURA 8 - Uma colheita da morte, Gettysburg, Pensilvânia, Timothy H. O'Sullivan, 1863 Fonte: Tudo sobre Fotografia, 2012

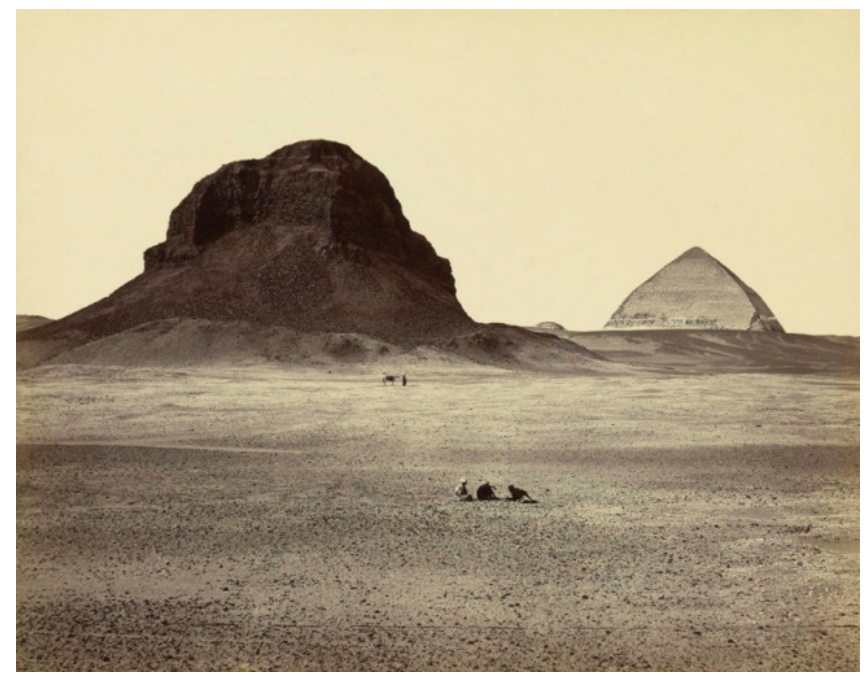

FIGURA 9 - As pirâmides de Dashur, Francis Frith, 1858

Fonte: Tudo sobre Fotografia, 2012 
A questão é que, atribuindo-se à fotografia todas essas tarefas e características objetivas, vinculou-se a ela a incumbência do registro do real. Tal ideia foi reforçada pela tentativa de engrandecer a pintura, em que muitos se valiam dos aspectos objetivos da fotografia para desmerecê-la como arte. Considerando-a um produto unicamente produzido pela câmera fotográfica, não poderia ser comparada à obra de arte, que era obtida pelo trabalho e talento manual do artista.

Crítico emblemático dessa discussão, o poeta francês Charles Baudelaire (1821-1867) repudiava a então obsessão francesa pelo "real", e via na fotografia o reforço para essa decadência de visão, sendo enfático em seu texto $O$ público moderno e a fotografia:

Quando se permite que a fotografia substitua algumas das funções da arte, correse o risco de que ela logo a supere ou corrompa por inteiro graças à aliança natural que encontrará na idiotice da multidão. É portanto necessário que ela volte a seu verdadeiro dever, que é o de servir ciências e artes, mas de maneira bem humilde, como a tipografia e a estenografia, que não criaram nem substituíram a literatura. (...) Mas se lhe for permitido invadir o domínio do impalpável e do imaginário, tudo o que só é válido porque o homem lhe acrescenta a alma, que desgraça para nós! (BAUDELAIRE, 1859, apud DUBOIS, 1998, p.29) ${ }^{10}$

Com o advento da Arte Moderna, o mundo já havia compreendido e aceitado a subjetividade do artista, afastando-o do papel de imitador do real. O desafio agora era entender que por trás do aparelho fotográfico estava o fotógrafo, com sua subjetividade, visão de mundo e ideais, e que ele poderia ser artista e a fotografia arte, e não apenas sujeito e instrumento da imitação da realidade.

As tentativas de elevar a fotografia ao status de arte passaram a ser frequentes ainda no século XIX. Alguns trabalhavam temas e motivos baseando-se no que era comum à pintura. Voltavam suas câmeras para assuntos como paisagens, ruínas e natureza morta, utilizando técnicas de composição artísticas. Também recorriam às imagens encenadas, em que se compunha uma espécie de narrativa, sendo nítida em algumas delas a influência das cenas renascentistas ${ }^{11}$.

No final do século XIX, a fim de contrariar a opinião então vigente, alguns fotógrafos chegaram a um resultado mais concreto para demonstrar que a fotografia também poderia ser arte. Essa empreitada ficou conhecida como Pictorialismo.

O intuito era aproximar as fotografias do aspecto visual das pinturas. Para tanto, trabalhavam com a alteração da granulação, efeitos de flou, e, especialmente, com manipulações posteriores diretamente no negativo ou no papel fotográfico, utilizando pincéis, lápis, agulhas de gravura, entre outros instrumentos.

Henry Peach Robinson (1830-1901), em seu livro Efeitos Pictóricos em Fotografia, estabelece algumas bases da fotografia pictorialista. Defendia que, além da técnica, o fotógrafo deveria ter experiência artística para alcançar o efeito pictórico, constituído de arte, natureza, autenticidade, beleza e artifícios de estúdio (Tudo so-

10 Posteriormente, Baudelaire dará indícios de aceitação da fotografia. Ele mesmo posa para retratos e envia cartas a fotógrafos pedindo cópias de imagens, reconhecendo que alguns deles estavam acima da mediocridade a eles apontada em suas críticas.

11 As cenas históricas e bíblicas eram frequentemente retratadas nas pinturas renascentistas. 
bre Fotografia, 2012).

São exemplos desse período os trabalhos de Alfred Stieglitz (1864-1946), Robert Demachy (1859-1936), Henry Peach Robinson (1830-1901), Oscar Gustave Rejlander (1813-1875) e Gertrude Käsebier. (1852-1934).

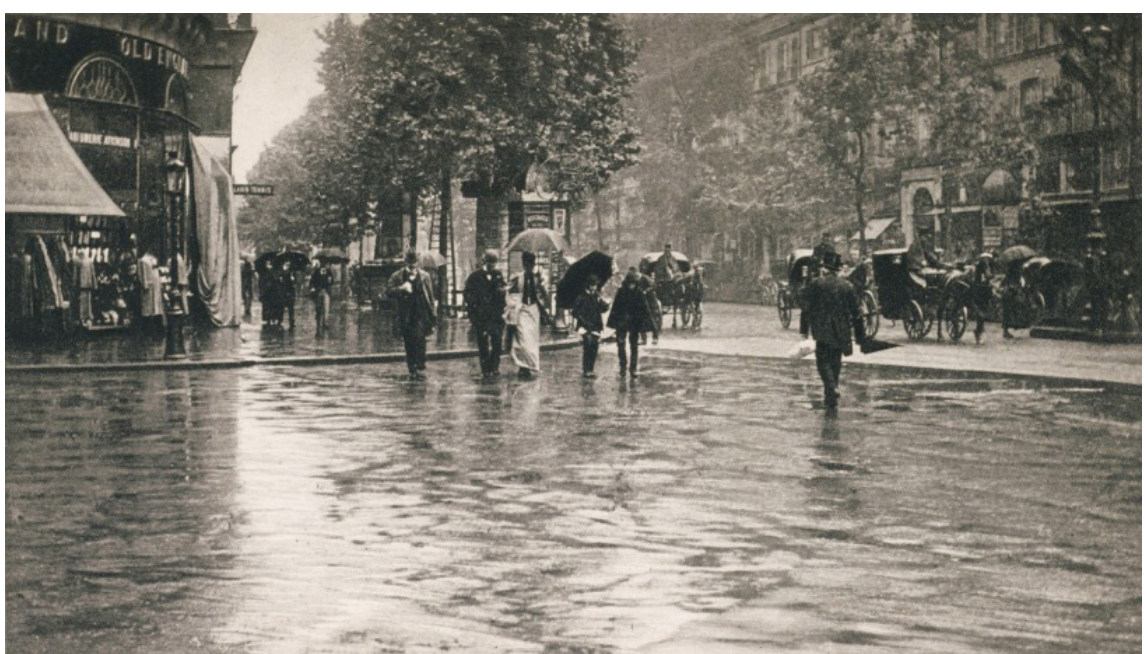

FIGURA 10 - A Wet Day on the Boulevard, Paris, Alfred Stieglitz, 1894 Fonte: http://www.moma.org/

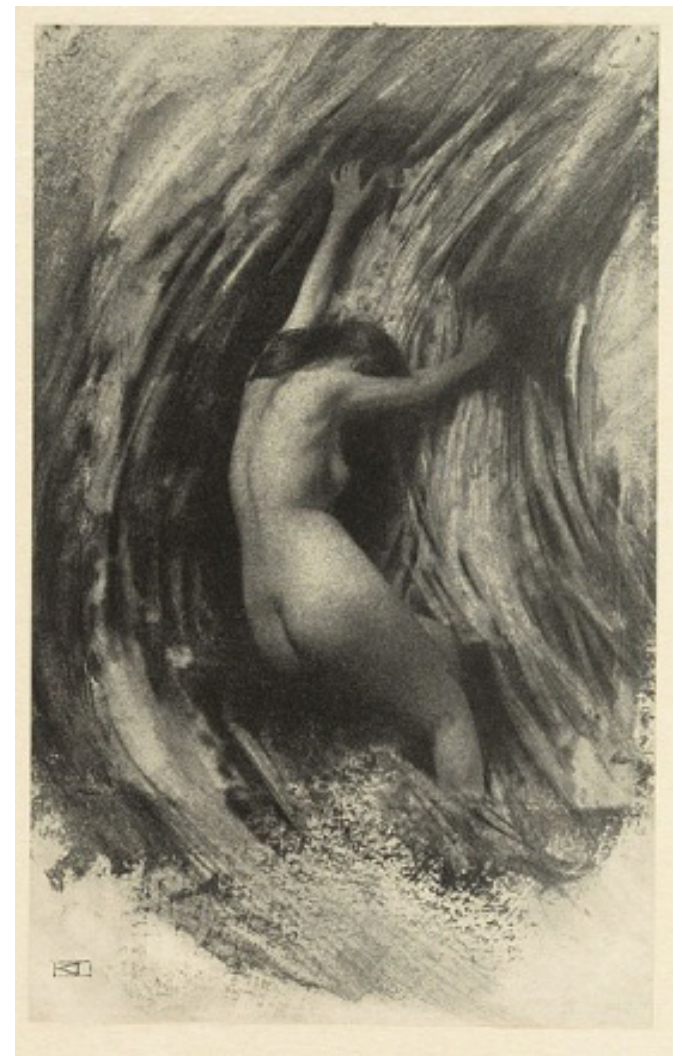

FIGURA 11 - Struggle, Robert Demachy, 1904 Fonte: http://www.photogravure.com 


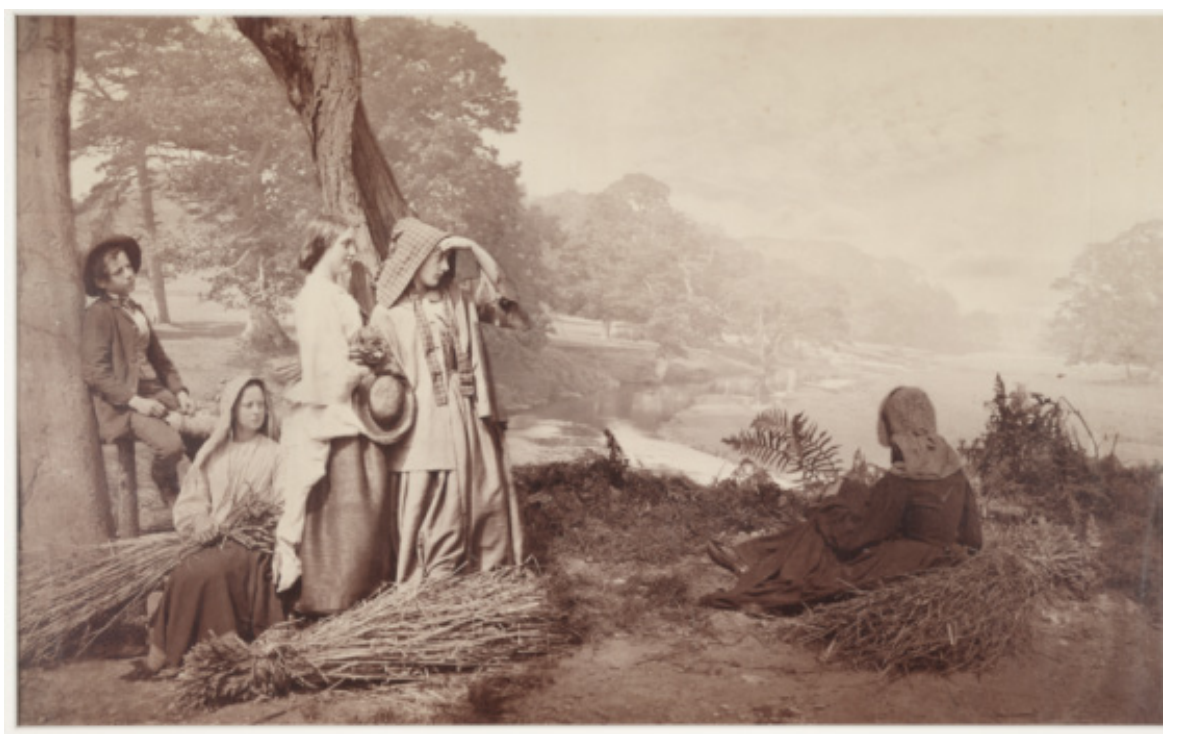

FIGURA 12 - Outono, Henry Peach Robinson, 1863

Fonte: http://www.nationalmediamuseum.org.uk

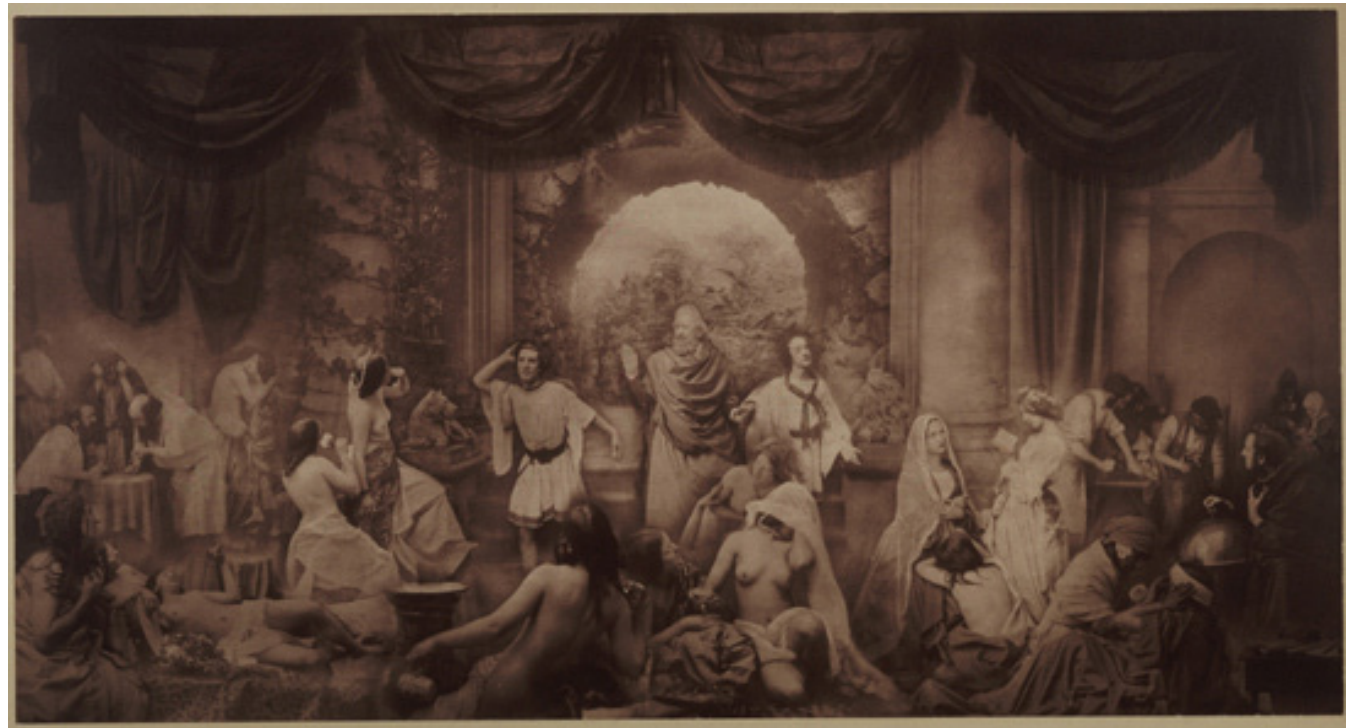

FIGURA 13 - Duas formas de vida, Oscar Gustave Rejlander, 1857

Fonte: http://blog.nationalmediamuseum.org.uk 


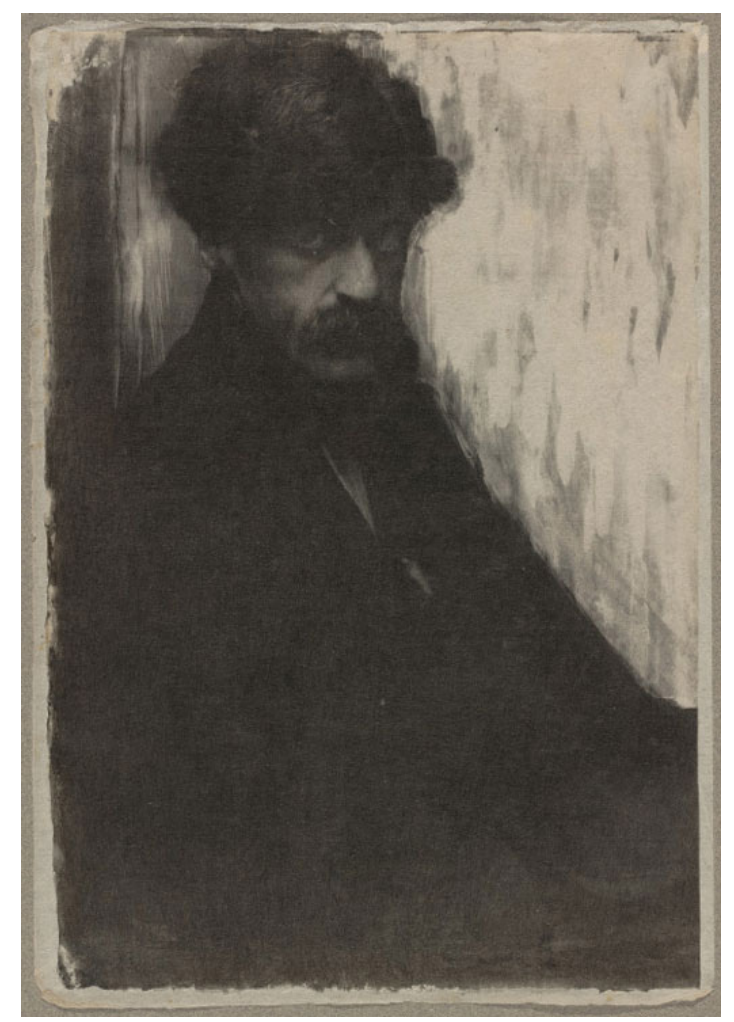

FIGURA 14 - Alfred Stieglitz, Gertrude Käsebier, 1902 Fonte: http://www.nga.gov

Embora tenham demonstrado com afinco a potencialidade do fotógrafo como artista, os pictorialistas não chegaram a explorar as possibilidades da fotografia como uma nova arte, apenas tentaram criar imagens semelhantes às pinturas.

Assim como no campo das artes plásticas, em que os artistas começavam a romper com os padrões estabelecidos e criar seus grupos independentes, os fotógrafos "artistas" passaram a se organizar em grupos e associações, o que culminou, em 1891, na Exposição Internacional de Fotógrafos Artísticos, em Viena. Depois desse evento, diversos grupos foram organizados por fotógrafos artistas, como o Linked Ring Brotherhood (1892), de Londres, O Photo-Club de Paris (1894) e os grupos vinculados às Secessões de Munique, Berlim e Viena.

O objetivo dessas organizações era libertar a fotografia de suas amarras documentais e técnicas e utilizá-la como uma forma de expressão artística. Seus membros acreditavam que a fotografia estava se tornando um processo mecânico objetivo, em vez de uma criação subjetiva e estética, de modo que começaram a utilizar técnicas de manipulação cada vez mais elaboradas. [...] Um número limitado de impressões era produzido a partir de um negativo, de modo a aumentar o valor do trabalho e enfatizar sua exclusividade. A apresentação também era fundamental, e a montagem, emolduração e exposição tornaram-se parte essencial do conjunto estético. (Tudo sobre Fotografia, 2012, p. 162).

Ainda se observa que as quebras de padrões até então conquistadas estavam relacionadas à fotografia ser ou não arte, não se trabalhava a sua identidade independentemente. Além disso, é curioso perceber que, ao mesmo tempo em que tentavam elevar a fotografia à arte, baseavam-se em conceitos estéticos pré-estabelecidos então superados pelas artes plásticas, que a essas alturas já estava em contato com os trabalhos de Cézanne e Van Gogh. 
Em 1902, Stieglitz, no auge de sua influência artística americana, criou em Nova lorque a Fotossecessão, estando fortemente influenciado pela fotografia pictorialista européia e o avanço do artista fotógrafo no tempo de seus estudos na Europa. "Seu objetivo foi mostrar que a fotografia era uma entidade autônoma: em vez de tentar imitar a arte do passado, a fotografia deveria simplesmente ser a forma principal de arte do século XX e além" (Tudo sobre fotografia, 2012, p. 177).

Tal experiência de grupo reuniu fotógrafos americanos simpatizantes da causa, como Edward Steichen (1879-1973), e culminou na revista trimestral Camera Work, fundada por Stieglitz, a qual era praticamente a revista institucional da Fotossecessão. A publicação ajudou a divulgar os ideais e a produção pictorialista, tanto de membros do movimento, quanto de convidados. Colaboraram como escritores figuras como George Bernard Shaw e Wassily Kandinsky.

Muito embora ter sido provado que a fotografia era uma arte independente e com potencial ilimitado na virada do século $\mathrm{XX}$, observa-se que todo o empenho despendido ainda foi sob um caráter mimético da imagem: os temas relacionados à paisagem, a natureza morta, retratos e situações encenadas, as manipulações pictorialistas antes ou depois da ampliação, e até mesmo a utilização de diversos negativos para compor uma só imagem, cujo intuito era duplicar pessoas e objetos.

Entretanto foi apenas uma questão de tempo para que o espírito modernista alcançasse a fotografia. $O$ anseio pela experimentação abriu caminhos para novas formas de ver o mundo através da objetiva e, reconhecido o caráter artístico, passaram a ser estudadas as questões da imagem fotográfica em si e seu processo de confecção. Com isso, a mimese obrigatória se perde e novas possibilidades são abertas.

O ânimo modernista entre os fotógrafos culminou em diferentes manifestações ao longo da primeira metade do século XX, algumas em conjunto com os movimentos de vanguarda, outras independentes. No entanto, para uma breve ilustração do rompimento do caráter mimético na fotografia, focaremos os trabalhos que se destacaram por essa característica, uma vez que tal distanciamento se deu de forma dispersa e não por um movimento específico.

A abstração foi uma das principais experimentações no rompimento da fotografia com a mimese. Foi explorada por Steichen e Stieglitz, que se voltou para o modernismo, distanciando-se do pictorialismo.

Stieglitz, em 1922, dedicou semanas ao seu fascínio pelas nuvens (FIGURA 15), fotografando-as com o intuito de atingir a mesma expressão abstrata proporcionada pela emoção da música, inspirado em artistas que admirava, como Wassily Kandinsky.

Steichen produziu imagens modernistas abstratas utilizando objetos para compor naturezas-mortas e dando um novo significado a eles (FIGURA 16). "Se era possível fotografar objetos fazendo-os sugerir algo inteiramente diferente, talvez fosse possível dar sentido abstrato a fotografias bem literais." (Tudo sobre fotografia, 2012, p. 197). 

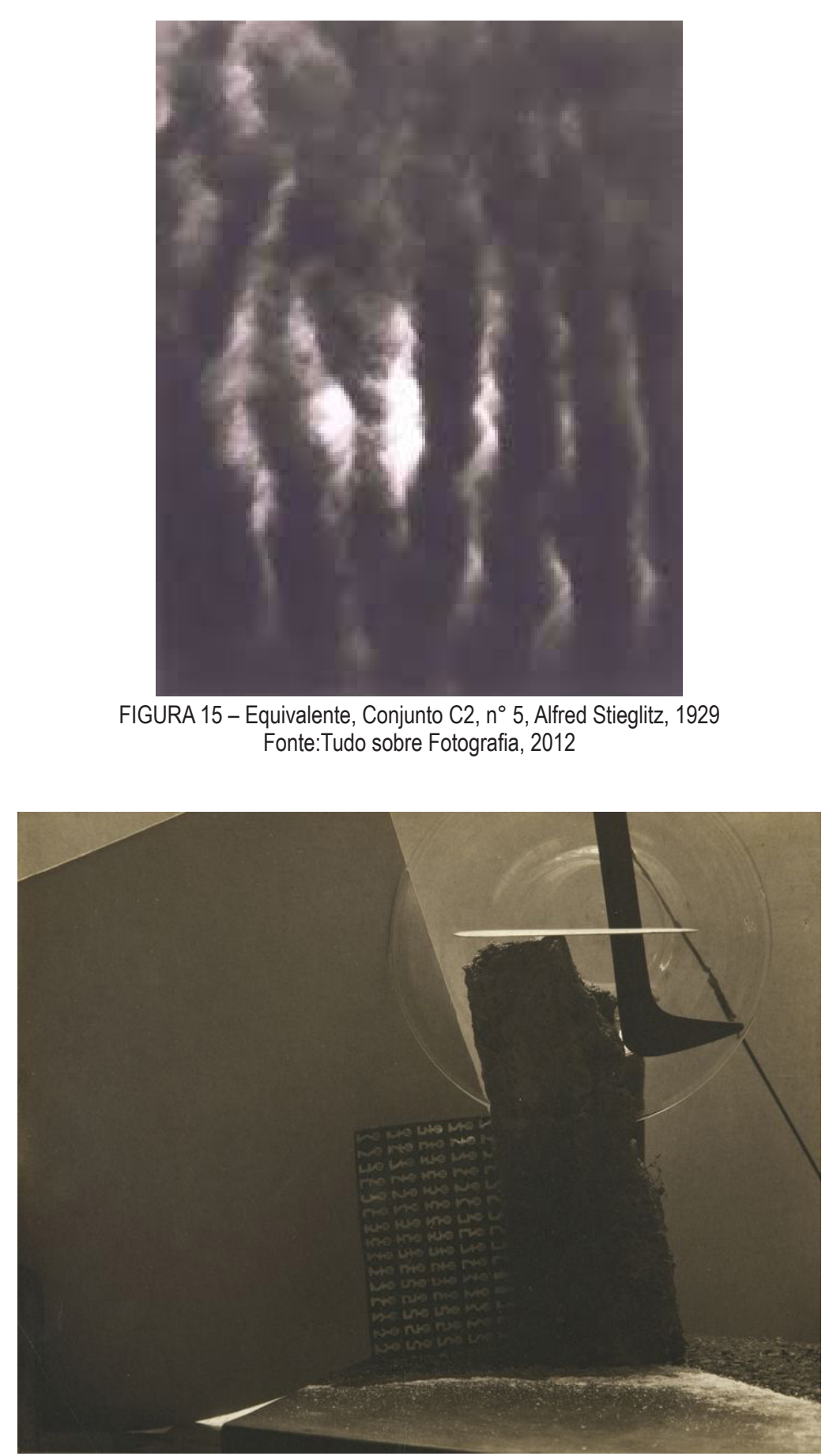

FIGURA 16 - Continuum Espaço-Tempo, Edward Steichen, 1920 Fonte: Tudo sobre Fotografia, 2012

Alvin Langdon Coburn (1882-1966) explorou as múltiplas exposições e os ângulos de perspectivas inusitados. Realizou imagens de alto de prédios e distorceu tetos de estações. No entanto, destacou-se por produzir fotografias abstratas a partir da composição visual fornecida por uma montagem que reunia vidros e madeira, em que a lente se encontrava inserida num arranjo triangular de espelhos, formando uma espécie de caleidoscópio, a que deu o nome de "vortóscopo". O resultado foram diversas imagens abstratas ("vortógrafos"), o que levou Coburn a ser um dos primeiros a realizar fotografias não figurativas (FIGURA 17). "Pense na alegria de fazer algo que seria impossível de classificar, ou de saber qual a parte de cima e de baixo." (COBURN, Tudo sobre fotografia, 2012, pg. 197) 

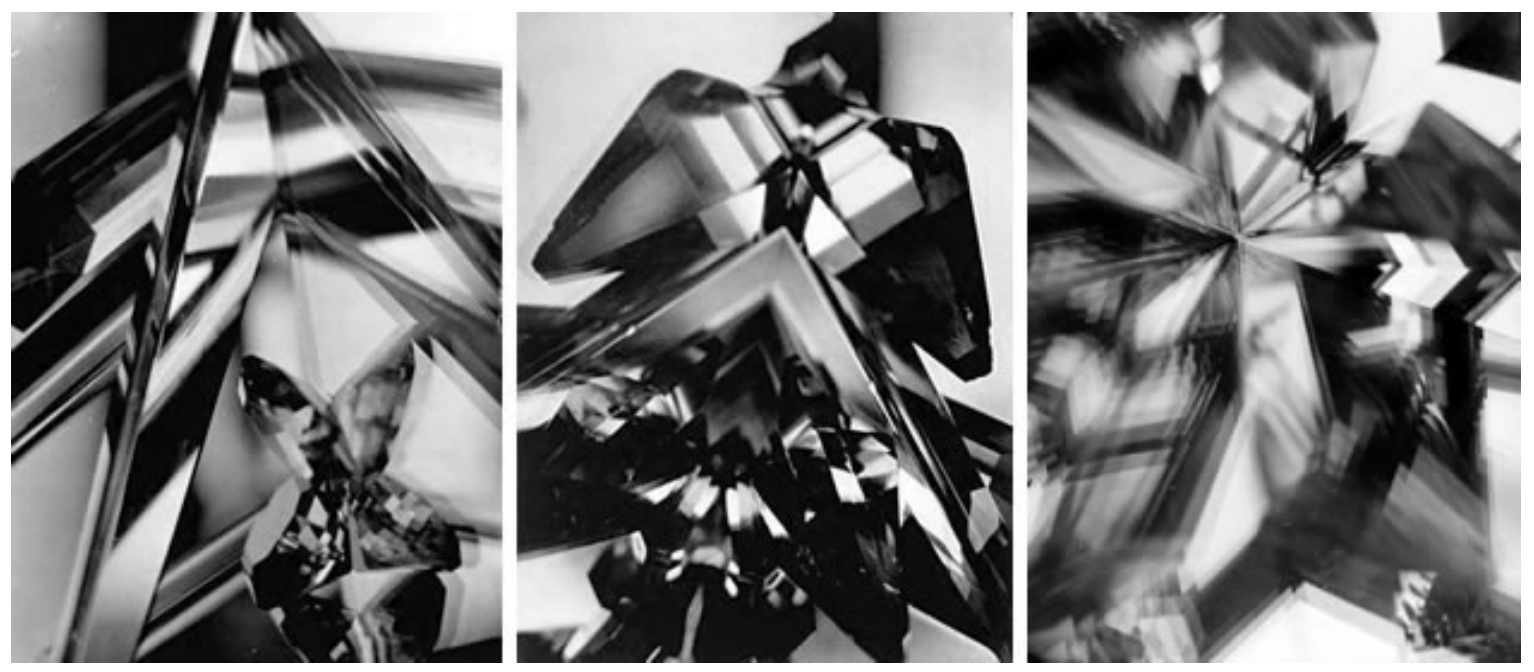

FIGURA 17 - Vortógrafos, Alvin Langdon Coburn, 1917

Fonte: http://www.studentartguide.com

Alguns fotógrafos simpatizantes do movimento futurista ${ }^{12}$ realizaram experimentos com o intuito de demonstrar na fotografia toda a atmosfera de progresso da época (tecnologia, máquinas, velocidade e movimento). Em 1911, os irmãos italianos Anton Giulio Bragaglia(1890-1960) e Arturo Bragaglia (1893-1962) conseguiram captar o movimento utilizando longa exposição e disparos de flashes repetitivos, denominando a técnica como "fotodinamismo". O movimento captado fornecia à imagem um aspecto fantasmagórico (FIGURA 18).

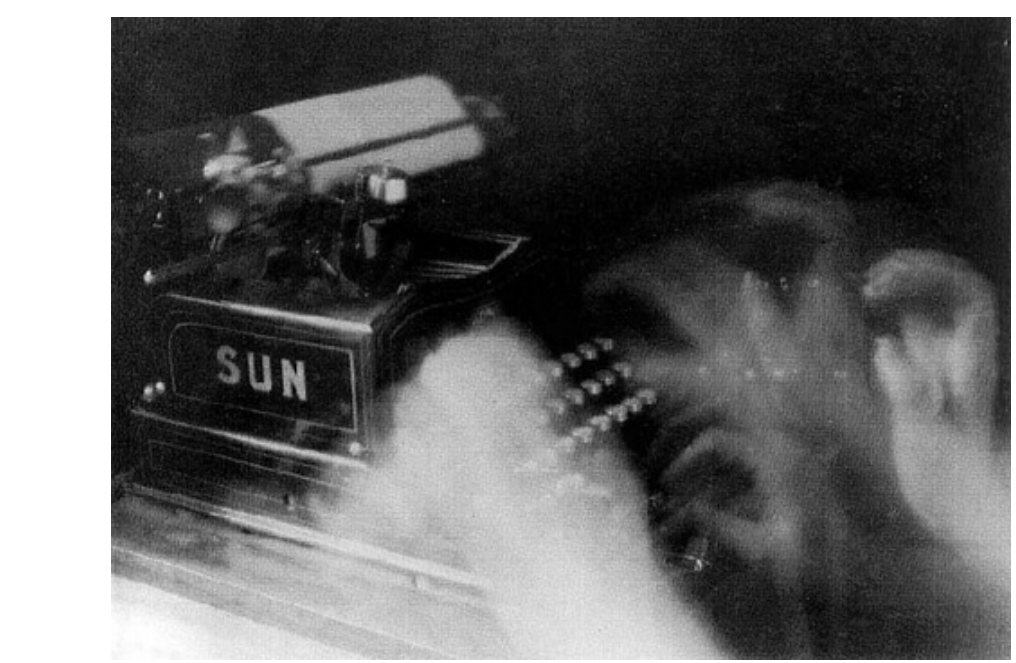

FIGURA 18- Máquina de escrever fotodinâmica, Anton Giulio Bragaglia e Arturo Bragaglia, 1911 Fonte: Tudo sobre fotografia, 2012

Dadaísmo ${ }^{13}$ teve a fotografia como um dos seus principais instrumentos de expressão. Com o auxílio dela, este movimento introduziu a prática da colagem e montagem, em que diversas fotografias (recortadas ou inteiras) eram reunidas em

120 Futurismo foi um movimento de vanguarda surgido em 1909, caracterizado pela valorização do mundo moderno e das conquistas industriais, como as máquinas. Associado a esta admiração, o movimento foi tema frequente das obras futuristas.

13 O Dadaísmo foi um movimento de vanguarda surgido em 1916, caracterizado por ser contestador e por utilizar diversos meios de expressão artística, desde a pintura até composições com objetos desordenados. 
uma nova composição, para ter um novo significado. Muitas vezes o resultado era uma imagem que não correspondia visualmente a algo existente visualmente na realidade. Experimentos com fotogramas abstratos também foram realizados por esses artistas (FIGURA 19).

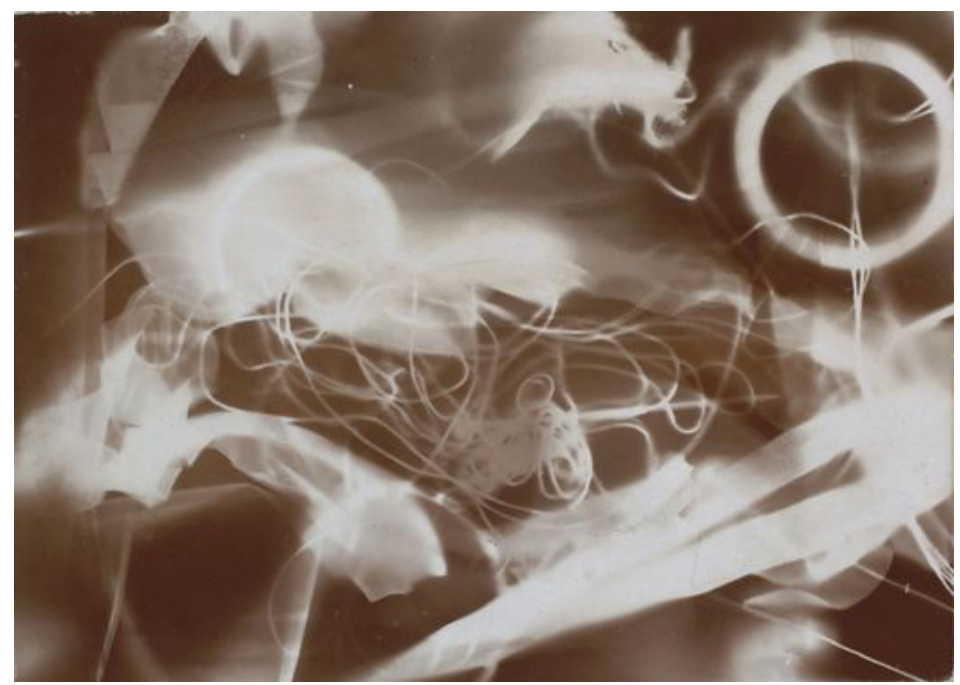

FIGURA 19 - Amourette, Christian Schad, 1918

Fonte: Tudo sobre fotografia, 2012

A questão da representação da realidade pela fotografia é curiosamente trabaIhada no movimento surrealista ${ }^{14}$. Autor do Manifesto Surrealista, o escritor francês André Breton (1896-1966) viu na fotografia um meio de retratar uma representação da realidade e não a própria realidade. Para ele, o enquadramento e a bidimensionalidade compunham a linguagem ideal para demonstrar que ali se encontrava uma representação e não uma replicação do real.

Considerado dadaísta e surrealista, o fotógrafo e artista plástico Man Ray (18901976) se destacou pelos experimentos e inovações na fotografia. Expressou-se por meio de montagens, colagens, agrupamentos, solarização, fotogramas, e as suas "rayografias", que eram, basicamente, os fotogramas realizados por ele, utilizando objetos do cotidiano, movimentando e mantendo-os a longas exposições (FIGURA 20). Esse leque de ferramentas fez dele um artista multifacetado, que procurava unir diversas formas de fazer arte em seus trabalhos.

140 Surrealismo foi um movimento de vanguarda surgido em 1924, caracterizado pelo afastamento da realidade concreta e criação de uma supra-realidade, exploração do subconsciente,valorização do sonho e do anti-racionalismo. 


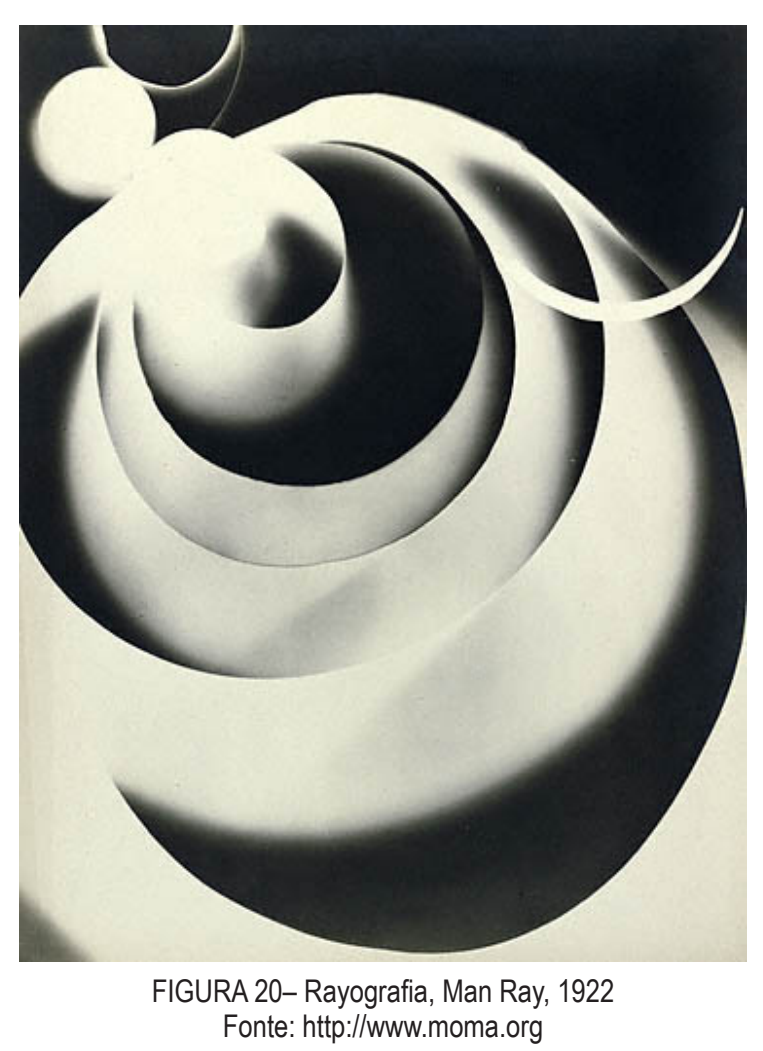

Percebe-se que o distanciamento da mimese na forma de representar não foi um movimento artístico ou cultural, não foi obrigatório, nem seguido por todos. Tratou-se de uma mudança em que antigos padrões foram quebrados e portas abertas para nunca mais serem fechadas. Representar a realidade tal como a vemos ainda faz parte do mundo artístico. A mimese também é instrumento de arte e está presente em várias manifestações visuais contemporâneas. Por outro lado, as formas conhecidas se mostraram insuficientes para os artistas mostrarem toda a complexidade de suas emoções, de suas visões de mundo e de si mesmos. A mimese ainda existe, contudo, não é mais imperativa e hoje temos a liberdade de dar qualquer forma à imaginação.

\section{CONCLUSÃO}

O distanciamento da mimese na fotografia não foi tão chocante quanto na pintura, uma vez que os seus primeiros anos de desenvolvimento ocorreram paralela ou conjuntamente às experimentações livres do modernismo. Quando isso se deu nas artes plásticas, foi um fenômeno envolto a áurea de revolução formal. Padrões estabelecidos desde o início do estudo das artes foram quebrados e uma nova forma de ver o mundo surgiu. A fotografia já encontrou algumas portas abertas no caminho para se distanciar do mimetismo, no entanto, a fascinante possibilidade de se obter uma cópia fiel do real fez dessa passagem uma tarefa complexa.

É natural que cresçamos entendendo melhor as representações miméticas, uma vez que imitam aquilo a que estamos acostumados em nossa realidade visual desde que nascemos. Ademais, ainda somos influenciados pelo meio a valorizar o aspecto real das coisas, basta lembrarmos nossas aulas de desenho e artes na escola, onde 
somos condicionados a representar o mundo de forma mimética e a seguir padrões visuais de formas e de cores. Ali nos é ensinado que as árvores não podem ser azuis e que colorir fora dos contornos é errado.

No entanto, entender o distanciamento da mimese na arte (e aqui podemos incluir todas as suas manifestações), é compreender que a subjetividade humana não tem forma determinada e que definir padrões para a expressão artística é limitar a criatividade. Mesmo na arte fotográfica, frente à possibilidade de se obter instantaneamente uma cópia fiel da realidade, o distanciamento da mimese foi inevitável.

\section{Referências Bibliográficas}

ARISTÓTELES. Arte Poética. Coleção a obra-prima de cada autor. Tradução de: Pietro Nassetti. São Paulo, SP: Martin Claret, 2003.

COSTA, L. M. A Poética de Aristóteles: mímese e verossimilhança. São Paulo, SP: Ática, 1992.

DUBOIS, P. O ato fotográfico e outros ensaios. 2. ed. Campinas,SP: Papirus, 1998.

GOMBRICH, E. H. A história da arte. 16. ed. Rio de Janeiro, RJ: LTC, 2008.

HACKING, J. (Org.). Tudo Sobre Fotografia. 1. ed. Rio de Janeiro, RJ: Sextante. 2012.

MAKOWIECKY, S; RAFFAELLI, R. Sobre a representação da natureza na pintura ocidental: mimesis e disegno interno. Cadernos de Pesquisa Interdisciplinar em Ciências Humanas, Florianópolis, v. 1, n. 11, p. 2-19, jan. 2000. ISSN 1984-8951. Disponível em: <https://periodicos.ufsc.br/index.php/cadernosdepesquisa/article/view/1693>. Acesso em: mai. 2015.

PLATÃO. A República. Coleção a obra-prima de cada autor. Tradução de: Pietro Nassetti. São Paulo, SP: Martin Claret, 2000. 


\section{Autor}

Ana Karina Tamoto do Prado

formanda do Curso Superior de Tecnologia em Fotografia da Universidade Tuiuti do Paraná, realizando trabalhos na área. Brasil.

anakarinaprado@yahoo.com.br 